\title{
A Review on Under Water Welding Process
}

\author{
C Sundarapandiyan \\ Assistant Professor, Department of mechanical Engineering \\ Ganesh College of Engineering, Salem - 636 111, Tamil Nadu, India.
}

A Balamurugan

Assistant Professor, Department of mechanical Engineering

Ganesh College of Engineering, Salem - 636 111, Tamil Nadu, India.

M Mohan

Assistant Professor, Department of mechanical Engineering

Ganesh College of Engineering, Salem - 636 111, Tamil Nadu, India.

\begin{abstract}
Welding in offshore and marine application is an area of research and understanding where, many problems are still unsolved. In the present paper, a brief classification of underwater welding is made, the principals involved and the advantages and disadvantages of the various types of underwater welding are described. Further discussion is made over the present conventional and some advanced techniques used. Finally, the scope of further research has been recommended. Welding in offshore and marine application is an area of research and understanding where, many problems are still unsolved. In the present paper, a brief description of the different commercial underwater techniques has been made. The problems in underwater welding have also been discussed in context to the existing welding techniques. Detailed description of a few advanced welding techniques has also been made. Finally, the scope of further research has been recommended.
\end{abstract}

Keywords: Welding techniques; Marine application.

\section{INTRODUCTION}

The fact that electric arc could operate was known for over a 100 years. The first ever underwater welding was carried out by British Admiralty - Dockyard for sealing leaking ship rivets below the water line. Underwater welding is an important tool for underwater fabrication works. In 1946, special waterproof electrodes were developed in Holland by 'Vander Willingen'. In recent years the number of offshore structures including oil drilling rigs, pipelines, platforms are being installed significantly. Some of these structures will experience failures of its elements during normal usage and during unpredicted occurrences like storms, collisions. Any repair method will require the use of underwater welding.

\section{CLASSIFICATION}

Underwater welding can be classified as

1) Wet Welding

2) Dry Welding

In wet welding the welding is performed underwater, directly exposed to the wet environment.

In dry welding, a dry chamber is created near the area to be welded and the welder does the job by staying inside the chamber. 


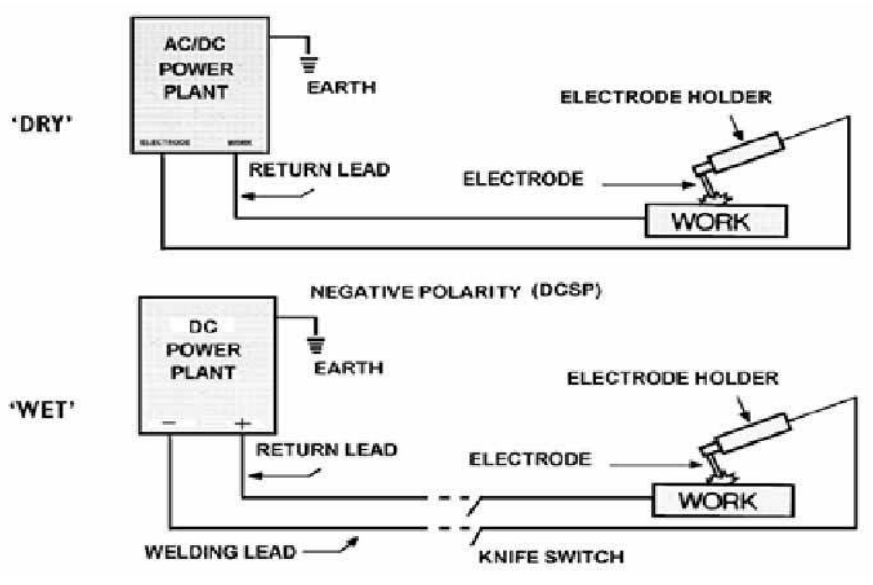

Fig. 1 Systematic Diagrams of Dry and Wet Welding Process

\section{WET WELDING}

Wet Welding indicates that welding is performed underwater, directly exposed to the wet environment. A special electrode is used and welding is carried out manually just as one does in open air welding. The increased freedom of movement makes wet welding the most effective, efficient and economical method. Welding power supply is located on the surface with connection to the diver/welder via cables and hoses.

POWER SUPPLY USED: DC

POLARITY: VE POLARITY

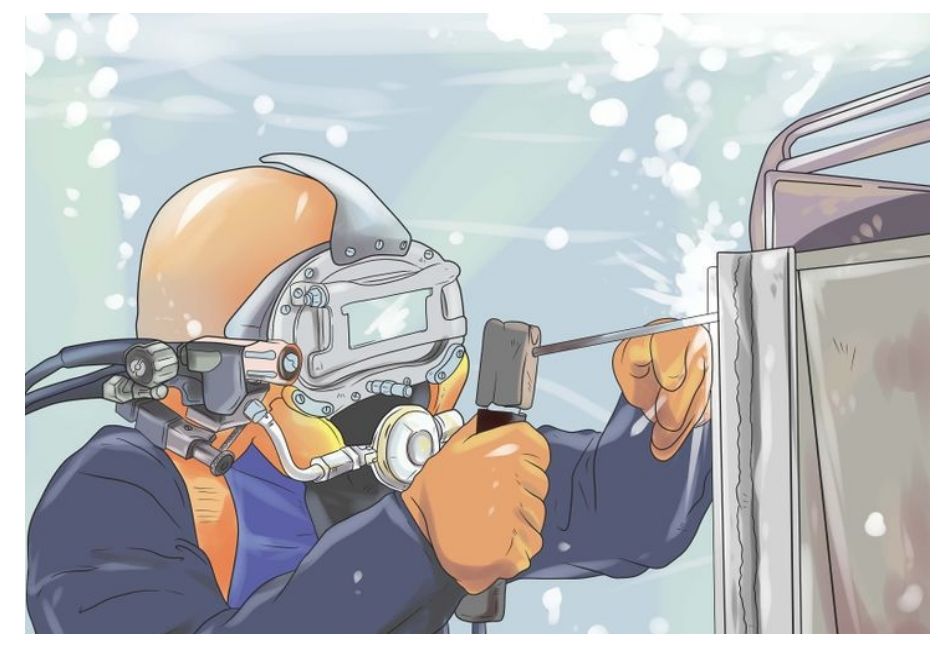

\section{PRINCIPLE OF OPERATION OF WET WELDING}

The process of underwater wet welding takes in the following manner:

The work to be welded is connected to one side of an electric circuit, and a metal electrode to the other side. These two parts of the circuit are brought together, and then separated slightly. The electric current jumps the gap and causes a sustained spark (arc), which melts the bare metal, forming a weld pool. At the same time, the tip of electrode melts, and metal droplets are projected into the weld pool. During this operation, the flux covering the electrode melts to provide a shielding gas, which is used to stabilize the arc column and shield the transfer metal. 


\section{PRINCIPLE OF OPERATION OF DRY WELDING}

Underwater welding in a dry environment is made possible by encompassing the area to be welded with a physical barrier (weld chamber) that excludes water. The weld chamber is designed and custom built to accommodate braces and other structural members whose centerlines may intersect at or near the area that is tobe welded. The chamber is usually built of steel, but plywood, rubberized canvas, or any other suitable material can be used. Size and configuration of the chamber are determined by dimensions and geometry of the area that must be encompassed and the number of welders that will be working in the chamber at the same time. Water is placed from within the chamber by air or a suitable gas mixture, depending upon water depth and pressure at the work site. Buoyancy of the chamber is offset by ballast, by mechanical connections and chamber to the structure, or by a combination of both.

\section{HYPERBARIC WELDING}

Hyperbaric welding is carried out in chamber sealed around the structure be welded. The chamber is filled with a gas (commonly helium containing 0.5 bar of oxygen) at the prevailing pressure. The habitat is sealed onto the pipeline and filled with a breathable mixture of helium and oxygen, at or slightly above the ambient pressure at which the welding is to take place. This method produces high-quality weld joints that meet X-ray and code requirements. The gas tungsten arc welding process is employed for this process. The area under the floor of the Habitat is open to water. Thus the welding is done in the dry but at the hydrostatic pressure of the sea water surrounding the Habitat.

\section{RISKS INVOLVED}

There is a risk to the welder/diver of electric shock. Precautions include achieving adequate electrical insulation of the welding equipment, shutting off the electricity supply immediately the arc is extinguished, and limiting the open-circuit voltage of MMA (SMA) welding sets. Secondly, hydrogen and oxygen are produced by the arc in wet welding.

Precautions must be taken to avoid the build-up of pockets of gas, which are potentially explosive. The other main area of risk is to the life or health of the welder/diver from nitrogen introduced into the blood stream during exposure to air at increased pressure. Precautions include the provision of an emergency air or gas supply, stand-by divers, and decompression chambers to avoid nitrogen narcosis following rapid surfacing after saturation diving.

For the structures being welded by wet underwater welding, inspection following welding may be more difficult than for welds deposited in air. Assuring the integrity of such underwater welds may be more difficult, and there is a risk that defects may remain undetected.

\section{CONVENTIONAL UNDERWATER WELDING TECHNIQUES}

The fusion welding processes of greatest practical significance in underwater welding are manual shielded metal arc welding, tungsten inert gas welding, metal inert gas welding are used [Khanna, 2004]. The principles of the above mentioned welding techniques are summarized below:

\section{SHIELDED METAL ARC WELDING}

Shielded Metal Arc Welding (SMAW) is among the most widely used welding processes. During the process, the flux covering the electrode melts during welding. This forms the gas and slag to shield the arc and molten weld pool. Fig. 2 shows the schematic of shielded metal arc welding process. The slag must be chipped off the weld bead after welding. The flux also provides a method of adding scavengers, deoxidizers, and alloying elements to the weld metal. 


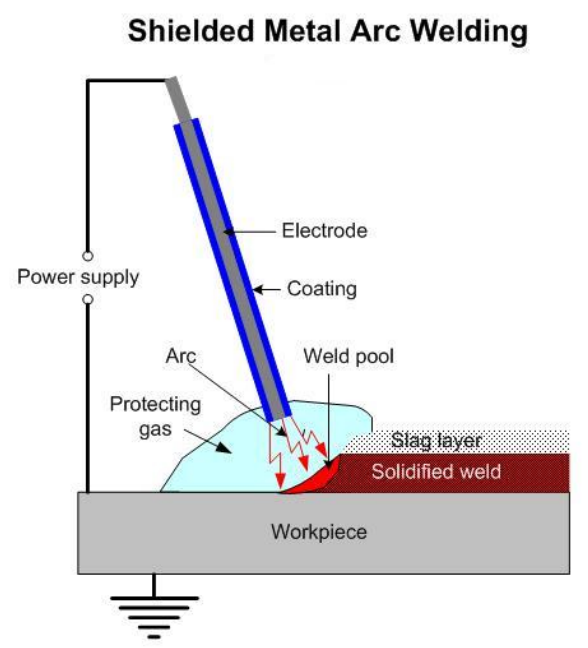

Fig. 2 Shielded Metal Arc Welding (SMAW)

For underwater wet welding with shielded metal arc welding (SMAW) technique, direct current is used and usually polarity is straight [Khanna, 2004]. Electrodes are usually water proofed. Furthermore, it is flux coated which causes generation of bubble during welding and displaces water from the welding arc and weld pool area.

Hence, the flux composition and depth of flux coating should be optimized to ensure adequate protection. Electrodes for shielded metal arc welding are classified by AWS as E6013 and E7014 [Khanna, 2004].Versatility, simple experiment set-up, economy in operation and finished product quality are notable advantages of the technique. However, during welding, all electrical leads, lighting gear, electrode holder, gloves, etc., must be fully insulated and in good condition. Ferrite electrodes with a coating based on iron oxide should be used as they resist hydrogen cracking. Flux cored arc welding is another technique which could not yet competed with SMAW because of reported excessive porosities and problems with underwater wire feeding system [Oates, 1996].

\section{FLUX CORED ARC WELDING}

Flux Cored Arc Welding (FCAW) is a commonly used high deposition rate welding process that adds the benefits of flux to the welding simplicity of MIG welding [Khanna, 2004]. As in MIG welding wire is continuously fed from a spool. Fig. 3 shows the schematic of flux cored arc welding process. Flux cored welding is therefore referred to as a semiautomatic welding process. Self shielding flux cored arc welding wires are available or gas shielded welding wires may be used. Less pre-cleaning may be necessary than MIG welding. However, the condition of the base metal can affect weld quality. Excessive contamination must be eliminated. Flux cored welding produces a flux that must be removed. Flux cored welding has good weld appearance (smooth, uniform welds having good contour). Flexibility in operation, higher deposition rate, low operator skill and good quality of the weld deposits are the notable advantages of flux cored arc welding. However, presence of porosities and burnback are the problems associated with the process. 


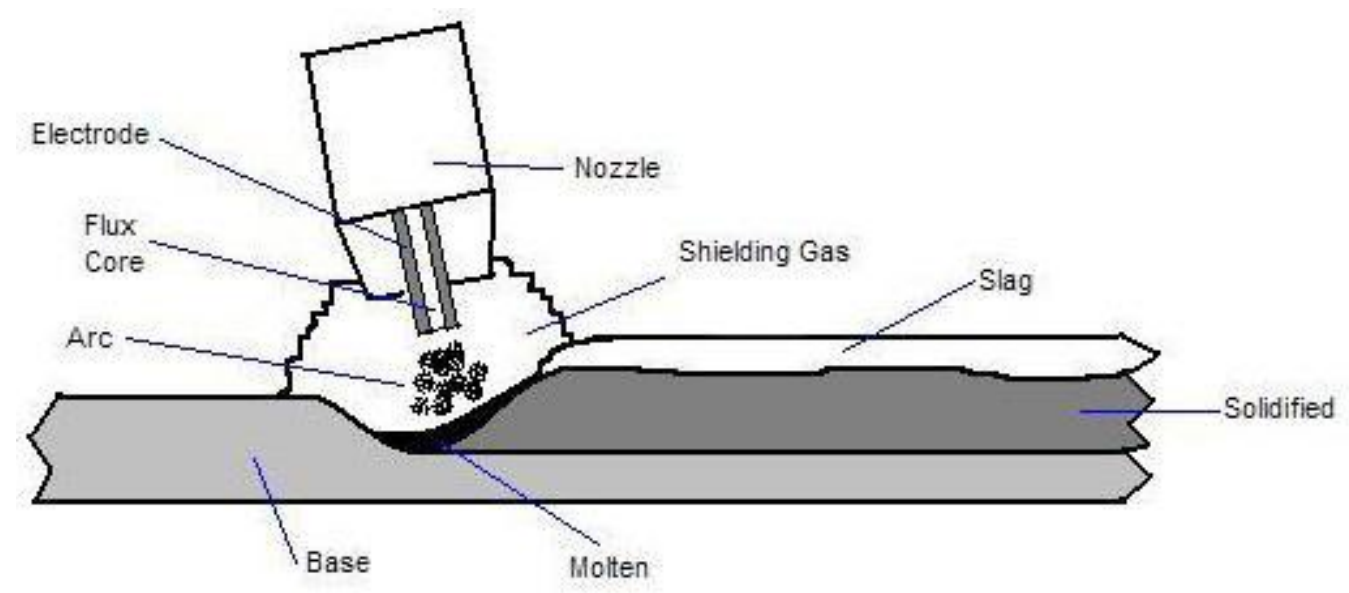

Fig. 3 Flux Cored Arc Welding (FCAW)

Recent development of nickel based flux cored filler materials have provided improved wet weldability and halogen free flux formulation specifically designed for wet welding application [Oates, 1996]. Similarly, improved underwater wet welding.

\section{CHARACTERISTICS OF A GOOD UNDER WATER WELDING}

1. Requirement of inexpensive welding equipment, low welding cost easy to operate, flexibility of operation in all positions.

2. Minimum electrical hazards, a minimum of $20 \mathrm{~cm} / \mathrm{min}$ welding speed at least.

3. Permit good visibility.

4. Produce good quality and reliable welds.

5. Operator should be capable in supporting himself.

6. Easily automated.

\section{APPLICATION OF UNDERWATER WELDING}

The important applications of underwater welding are:

1. Offshore construction for tapping sea resources.

2. Temporary repair work caused by ship's collisions or unexpected accidents.

3. Salvaging vessels sunk in the sea.

4. Repair and maintenance of ships.

\section{UNDERWATER WELDING - FUTURE SCOPE OF RESEARCH}

Considerable research effort has been made to improve process performance and control strategies for the various underwater welding processes over the last half century. However, there are still many problems to overcome. The major efforts on research and development should be focused on the following topics:

1. Automation of the underwater joining and inspection of the welded structures.

2. Mechanized underwater welding for actual Investigation of the potential of using a robot manipulator for underwater ultrasonic testing of welds in joints of complex geometry.

3. Application of advanced welding technique, like friction, laser welding and understand the behavior of 
materials after the welding and process optimization.

4. Invention of new welding techniques and explore the possibility of its application in underwater welding.

5. Generation of research data book on weld ability of materials during underwater welding.

\section{REFERENCES}

[1] D. J Keats, Manual on Wet Welding.

[2] Annon, Recent advances in dry underwater pipeline welding, Welding Engineer, 1974.

[3] Engineering materials and metallurgy by v.jaya kumar, A.R.S. Publications.

[4] W.Lucas, International conference on computer technology in welding.

[5] Silva, Hazlett, Underwater welding with iron- powder electrodes, Welding Journal, 1971.

[6] Hugel H, Matthias G, Muller G, et al. (1999): Proc SPIE, Vol. 3571, pp. 52-60.

[7] Irie T, Ono Y, Matsushita H, et al. (1997): Proceedings of 16th OMAE, pp. 43-50.

[8] Kern, M, Berger, P., Ugel, H. H., (2000), Weld. J., Vol. 3, pp. 72. , O. P. (2004): A Textbook of Welding Technology, Dhanpat Rai Publications (P) Ltd., N. Delhi,India.

[9] Kruusing, A. (2004): Optics and Lasers in Engineering, Vol. 41, pp. 329-352. Lancester, J. F. (1987): The Physics of Fusion Welding Part I: The Electric Arc in Welding, IEE Proc., Vol.134, pp. 233-254.

[10] Oates W. A. (ed.) (1996): Welding Handbook, Vol. 3, American Welding Society, Miami, USA. 